\title{
ANTIBODY RECOGNITION OF AN 18 KDA PROTEIN POSSIBLY INVOLVED IN PHOSPHATE REMOVAL BY ACTIVATED SLUDGE
}

\author{
A. S. ERASMUS, S. VAN WYNGAARDT, J. A. VERSCHOOR, M. M. EHLERS, J. VAN \\ HEERDEN and T. E. CLOETE
}

\begin{abstract}
Abbreviations $-A_{540}$, absorbance at $540 \mathrm{~nm}$; BSA, bovine serum albumin; $M_{r}$, molecular mass; PBS, phosphate buffered saline, $\mathrm{pH}$ 7.2; S.D., standard deviation; SDS-PAGE, sodium dodecyl sulphate polyacrylamide; TBS, tris buffered saline
\end{abstract}

\section{INTRODUCTION}

Phosphate has been implicated in eutrophication, an undesirable phenomenon of overgrowth of water plants and algae in water systems, necessitating legal restrictions on the levels of soluble phosphate in effluents from wastewater treatment systems (Cooper et al, 1994). The success of enhanced biological phosphate removal (EBPR) by polyphosphate accumulating (polyP) bacteria in activated sludge has spawned much research interest, but its mechanisms remain far from fully elucidated.

Many variations of the EBPR process exist, all utilising the same mechanism, but applied in different ways to select for polyP organisms and achieve phosphate removal (Cooper et al., 1994). Enhanced biological phosphorus removal receives increased interest due to the low sludge production, the fertiliser value of the sludge and the use of the waste-water components as "chemical" for the process (Henze, 1996). A primary requirement for phosphate removal is the recirculation of the sludge through alternating anaerobic and aerobic stages, anaerobic indicating an environment free of dissolved oxygen as an electron acceptor. These conditions suit acidogenic microflora, which convert organic substrate to short-chain volatile fatty acids such as acetate. The polyP bacteria take up the acetate and store it as polyhydroxy-butyrate (PHB). The energy for transport and storage is provided by the hydrolysis of an intracellular polyphosphate reserve to phosphate, resulting in phosphate release from the cell (Fleit, 1995). In the aerobic zone the bacteria utilise the accumulated PHB reserves to generate energy for the synthesis of new biomass and for polyphosphate synthesis, accompanied by the uptake of phosphate from the sludge liquor (Kortstee et al., 1994). In plants where nitrate removal is also required, an additional anoxic stage for denitrification is needed. The term "anoxic" indicates an environment free of dissolved oxygen, but oxygen is available as part of the nitrate ion (Schön et al., 1993).

Monoclonal antibody production is the method of choice to obtain immunoglobulins against proteins that cannot be purified or that are available in low amounts. Antibodies have been used previously in investigations of samples from activated sludge systems, although such studies are not numerous. Monoclonal antibodies specific for Nitrobacter and Nitrosomonas were produced and used for estimation of cell numbers in activated sludge (Sanden et al., 1994).

Conventional as well as focused immunisation strategies were used in this study to maximise the possibility of producing antibodies with the required ability to discern between the antigen preparations. The cytotoxic, immunosuppressant drug cyclophosphamide was used as tolerising agent to manipulate the bias of the normal immune response. All proliferating lymphocytes stimulated by a preceding immunisation are eliminated by cyclophosphamide administration, thus suppressing the immune response of mice immunised against either of the antigens. Subsequent immunisation of such mice with the alternative antigen preparation should direct the immune response at those determinants that had been absent from the former antigen preparation used. Matthew and Patterson (1983) and Matthew and Sandroch (1987) were the first to effectively employ this approach to develop highly specific antibodies to impure material.

The search for antigenic differences between the anoxic and aerobic zones as conducted in this study was aimed at detection of significant quantitative differences of expression of an antigen specifically involved in phosphate uptake in the aerobic zone, possibly induced by the introduction of oxygen to the environment. In the anaerobic zone the lack of oxygen as a terminal electron acceptor results in an increase in the NADH level, inhibiting oxidative metabolism (such as the tricarboxylic acid cycle). The resultant increase in acetyl CoA levels stimulates polyhydroxybuterate (PHB) synthesis, while polyphosphate degradation is stimulated by the decrease in the ATP/ADP ratio in the absence of oxidative phosphorylation (Smolders et al, 1994a). In the aerobic zone, oxygen is utilised as final electron acceptor for the electron transport system by which the high NADH level is reduced. Inhibition of the tricarboxylic acid cycle is relieved permitting oxidation of 
stored substrate (polyhydroxybuterate). Oxidative phosphorylation proceeds and ATP is produced. Phosphate is actively transported into the cell and polyphosphate synthesis proceeds (Smolders et al, 1994b). Only recently has the phenomenon of denitrification by polyphosphate organisms, and therefore the uptake of phosphate in the anoxic zone, been incorporated in modelling of the activated sludge process (Mino et al, 1995). This was due to the observation that phosphate is sometimes taken up in the sludge under anoxic conditions. The existence of two groups of phosphate accumulating bacteria was postulated: one group capable of utilising only oxygen as electron acceptor and the other group capable of utilising both oxygen and nitrate as electron acceptor, i.e. denitrifying polyP organisms (Mino et al, 1995; Sorm et al, 1996). The anoxic zone sample utilised in the current study was obtained from the second anoxic zone of a modified UCT system. This zone receives nitrified mixed liquor from the aerobic zone directly (Knight et al., 1995), so that adequate levels of nitrate to sustain the uptake of phosphate are likely to be present. The difficulty experienced in finding antibodies against antigens unique to the aerobic zone might be explained by the possible presence of such denitrifying polyP organisms in this system: antigens expressed by these for the purpose of phosphate uptake would already be present in the anoxic zone through the feed-back from the aerobic zone. The extent of phenotypic similarity between the anoxic and aerobic zones would be increased, thereby further obscuring those antigens uniquely expressed in the aerobic zone by that group of polyP organisms restricted to oxygen as final electron acceptor.

This study was aimed at the development of immunochemical probes to determine and monitor phenotypic traits of the activated sludge phosphate removal process. The antibodies were tested for use in evaluation of the phenotypic status pertaining to different zones in a phosphate removing system. The possibility was also investigated that monoclonal antibodies could distinguish between activated sludge systems with differing phosphate removal abilities.

Table 1. Operational parameters of two activated sludge systems with different phosphate removal ability

\begin{tabular}{|c|c|c|}
\hline Parameter & System removing phosphate successfully & System removing phosphate unsuccessfully \\
\hline Sludge age (days) & 10 & 10 \\
\hline Temperature $\left({ }^{\circ} \mathrm{C}\right)$ & 30 & 30 \\
\hline \multicolumn{3}{|l|}{ Chemical oxygen demand (mg COD/1): } \\
\hline Influent & 760 & 760 \\
\hline Effluent & 55 & 50 \\
\hline \multicolumn{3}{|l|}{ Total phosphate $\left(\mathrm{mg} \mathrm{PO}_{4}^{-}-\mathrm{P}^{-1}\right)$} \\
\hline Influent & 16.5 & 16.5 \\
\hline Effluent & 1.7 & 8.6 \\
\hline Phosphate removal $\left(\mathrm{mg} \mathrm{PO}_{4}^{-}-\mathrm{P}^{-1}\right)$ & 14.8 & 7.9 \\
\hline
\end{tabular}

\section{MATERIALS AND METHODS}

\section{Samples of activated sludge}

For immunisation and screening. Samples were taken from the second anoxic and the aerobic zones of a stable laboratory scale activated sludge system of the modified UCT (University of Cape town) configuration (Toerien et al, 1990). This system had an anaerobic zone followed by two, i.e. the primary and secondary anoxic zones. The return sludge is discharged to the primary anoxic reactor, while the nitrified, mixed liquor from the aerobic zone is recycled to the second anoxic reactor for denitrification. The anaerobic zone receives recycled, denitrified, mixed liquor from the primary anoxic reactor only, facilitating maintenance of its nitrate-free status. The system showed good phosphate removal $(11.43 \mathrm{mg}$ $1^{-1} \mathrm{PO}_{4}^{3}-\mathrm{P}$ removed at the time of sampling).

For comparative studies of systems with different phosphate removal abilities. Samples were simultaneously taken from the aerobic zones of two laboratory scale systems receiving identical daily inflow. The systems differed only in configuration: the first, being a UCT system, removing phosphate significantly; the other, lacking the anaerobic zone at the head of the system, comparatively weak at phosphate removal. Table 1 shows the operational parameters of the two systems. After collection, samples were immediately fixed by addition of formalin to $0.25 \%(\mathrm{v} / \mathrm{v})$, incubated at $10^{\circ} \mathrm{C}$ for $24 \mathrm{~h}$, and stored at $4^{\circ} \mathrm{C}$. 


\section{Antigen preparation}

Flocs were disrupted by shaking anoxic or aerobic zone samples with glass beads in a mechanical shake apparatus (Edmund Bühler Type Vi2, Tübingen, Germany). Loose cells were separated from remaining flocs and other organic material by low speed centrifugation (45 x g. Hermle Z320 centrifuge, Germany) for $10 \mathrm{~min}$. Cell fractions $\left(10^{6}\right.$ dilution) were washed with double distilled deionised water three times and centrifuged at $10000 \mathrm{x} g$ for 20 min (Beckman L7-55 Ultracentrifuge, Germany). As a relative measure of cell density, $A_{540}$ of 0.1 was arbitrarily taken as $10^{8}$ cells $\mathrm{ml}^{-1}$. Cell suspension volumes of $0.5 \mathrm{ml}$ each were lysed by sonication on ice for $4 \mathrm{~min}, 50 \%$ pulsed, at maximal energy input (Sonifier Cell Disruptor B-30, Branson, U.S.A.). Whole cell fractions were combined with lysed fractions in a 1:1 ratio to obtain final antigen preparations.

\section{Immunisation}

Two groups of C57B1/6J mice (H.A. Grove Research Centre, Pretoria) were used, four to six weeks old at the start of the immunisation programme. These were intra-peritoneally injected with $0.5 \mathrm{ml}$ of either the aerobic or the anoxic antigen preparation, freshly prepared and diluted with $0.9 \%(\mathrm{w} / \mathrm{v}) \mathrm{NaCl}$ to $2 \times 10^{7}$ cells $\mathrm{ml}^{-1}$. Mice were immunised at $0,2,6,10$ and 14 weeks.

Immunofocusing. A subset of the mice in the two groups was subjected to immunofocusing (based on the protocol followed by Crause, 1993). Four days after week 14 immunisation, $40 \mathrm{mg}$ of cyclophosphamide (Sigma, U.S.A.) per $\mathrm{kg}$ body weight in $0.5 \mathrm{ml} 0.9 \%(\mathrm{w} / \mathrm{v}) \mathrm{NaCl}$ was administered intraperitoneally. Subsequent immunisations using the alternative antigen preparation were performed ten days after immunosuppression, and again at 18, 22, 28 and 32 weeks. Antisera were obtained by bleeding mice one week after immunisation.

\section{Hybridoma production}

The general method of Galfré and Milstein (1981) was used to produce hybridomas, both from the unfocused mice as well as the immunofocused mice.

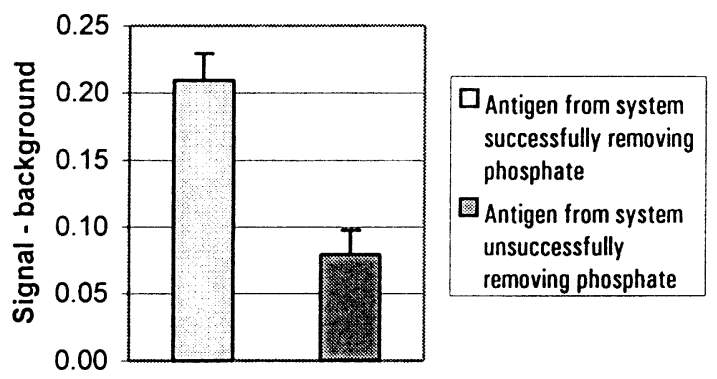

Fig. 1. Comparison of activated sludge systems with differing phosphate removing abilities by ELISA using monoclonal antibody 7B9. The procedure is detailed in Section Materials and methods, using casein buffer supplemented with horse serum. Supernatant from Sp2/0 cultures was used as negative serum control. Results are the mean \pm S.D. of eight values.

\section{ELISA procedures}

Screening. Aerobic or anoxic zone antigen preparations, freshly prepared and diluted with PBS to $2 \mathrm{x}$ $10^{8}$ cells ml $^{-1}$ were used for coating of microtitre plates (Sterilin, England) at $100 \mu 1$ per well. The plates were dried by means of a heating lamp and fan. After fixation with $200 \mu \mathrm{l}$ of $70 \%$ methanol per well for $10 \mathrm{~min}$, the methanol was shaken out and the plates kept at $4^{\circ} \mathrm{C}$ until use (Smith, 1988). Casein (Merck, Germany) at $0.5 \%(\mathrm{w} / \mathrm{v})$ in PBS was used for blocking against nonspecific binding, washing, and dilution of sera and immunoglobulin peroxidase conjugates. Antisera were optimally diluted at 1/80. In some experiments (see legends to Figs 1-3), 5\% horse serum was included in the blocking buffer as this diminished nonspecific binding presenting as high background signals. Antigen coated wells were blocked for 1 to $2 \mathrm{~h}$ before incubation with undiluted hybridoma culture supernatants or diluted antisera at $50 \mu \mathrm{l}$ per well for $45 \mathrm{~min}$, all at room temperature. The plates were washed three times, aspirated and incubated with a 1:4000 dilution of goat anti-mouse IgG (heavy and light chain) peroxidase conjugate (Cappel, U.S.A.) at $50 \mu \mathrm{l}$ per well for $30 \mathrm{~min}$ at room temperature. The plates were again washed three times and aspirated. Colour development followed at room temperature by adding to each well $50 \mu 1$ of 
a substrate solution consisting of $0.1 \%(\mathrm{w} / \mathrm{v}) o$-phenylenediamine (Sigma, U.S.A.) and $0.08 \%(\mathrm{w} / \mathrm{v})$ urea hydrogen peroxide (BDH Chemicals, UK) in $0.1 \mathrm{~mol}^{-1}$ citrate buffer, $\mathrm{pH}$ 4.5. Absorbance was read at $450 \mathrm{~nm}$ on an ELISA spectrophotometer (SLT Lab Instruments, Austria).

Isotyping of antibodies. A similar ELISA procedure as described above was used, but utilising either a rabbit anti-mouse $\gamma$-chain peroxidase conjugate, or a rabbit anti-mouse $\mu$-chain peroxidase conjugate (Cappel, U.S.A.).

\section{Antigen characterisation}

Trypsin digestion of antigen. Freshly prepared aerobic zone antigen preparations were diluted with PBS to $210^{8}$ cells ml ${ }^{-1}$. Trypsin (Boehringer Mannheim, Germany), reconstituted in $0.1 \mathrm{mM} \mathrm{HC1}$, was immediately added to a concentration of $0.2 \%(\mathrm{w} / \mathrm{v})$ and incubated for $16 \mathrm{~h}$ at room temperature (Boshoff, 1991). Trypsin was withheld from control specimens. Presence or absence of proteolytic activity was confirmed by adding a drop of the reaction solution to a few drops of a substrate solution (40 mM N-benzoyl-DL-arginine 4-nitroanilide-HCl (Merck, Germany) in DMSO, diluted ten-fold before use). Development of a yellow colour indicated activity (Geiger and Fritz, 1984). Trypsinated antigen preparations were used for coating of microtitre plates, and ELISA was carried out as described for screening.

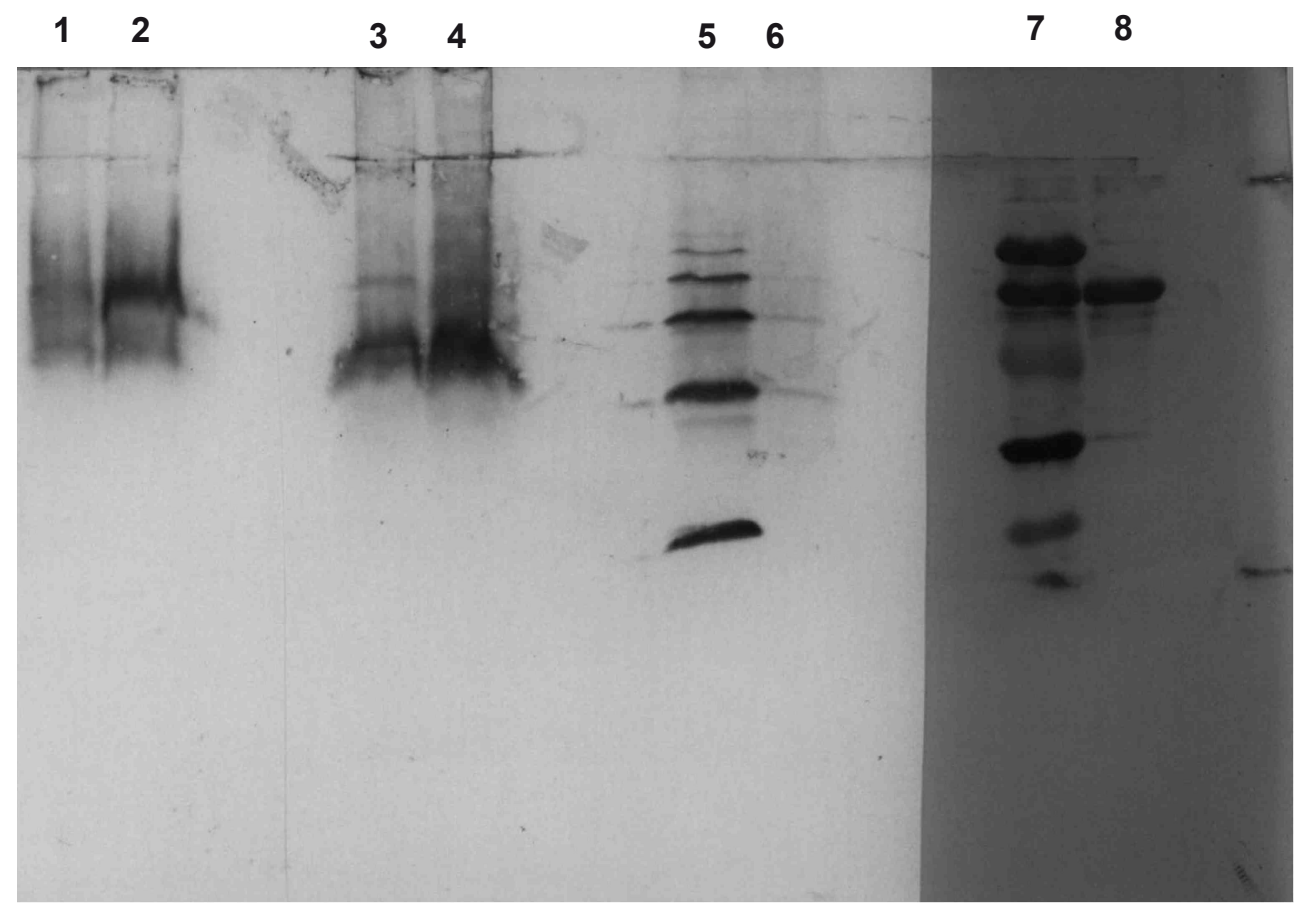

Fig. 2. Immunoblot comparison of reduced SDS-PAGE antigen preparations from activated sludge systems with differing phosphate removing abilities. Lane 1: the system successful at phosphate removal; lane 2: the system less successful at phosphate removal. Antigens were probed with monoclonal antibody 7B9. Coomassie blue stained low $M_{r}$ markers $(\mathrm{kDa})$ and BSA are shown in lanes 3 and 4 , respectively.

Periodate oxidation of antigen. Freshly prepared aerobic zone antigen preparations were diluted to concentrations of $2 \times 10^{8}$ cells ml $^{-1}$ in $50 \mathrm{mM}$ sodium glutamate buffer, $\mathrm{pH} 4.5$, containing $20 \mathrm{mM}$ periodic acid (Merck, Germany). Periodic acid was withheld from control specimens. After $1 \mathrm{~h}$ incubation at $4{ }^{\circ} \mathrm{C}$, glycerol was added to a final concentration of $20 \mathrm{mM}$ and the $\mathrm{pH}$ was adjusted to 7.2. The oxidation step was stopped by adjusting the $\mathrm{pH}$ to 9.2 with $1 \mathrm{M} \mathrm{NaOH}$ (Furniss et al, 1989). Presence or absence of periodate oxidative activity was confirmed before and after this step by adding a drop of the reaction solution to a few drops of $0.1 \mathrm{~mol} \mathrm{l}^{-1}$ potassium iodide solution: development of a yellow colour indicating a positive result (Boshoff, 1991; Moreno et al., 1994). Periodate oxidised antigen preparations were used for coating of microtitre plates and ELISA was carried out as described for screening. 


\section{SDS-PAGE and immunoblotting}

SDS-PAGE was performed as described by Laemmli (1970). The separating gel was composed of $0.38 \mathrm{~mol} \mathrm{l}^{-1}$ Tris- $\mathrm{HCl}, \mathrm{pH} 8.8,0.1 \%(\mathrm{w} / \mathrm{v})$ SDS, $12 \%(\mathrm{w} / \mathrm{v})$ acrylamide and $0.3 \%(\mathrm{w} / \mathrm{v}) N^{\prime}, N^{\prime}-\mathrm{Bis}-$ methylene-acrylamide. The
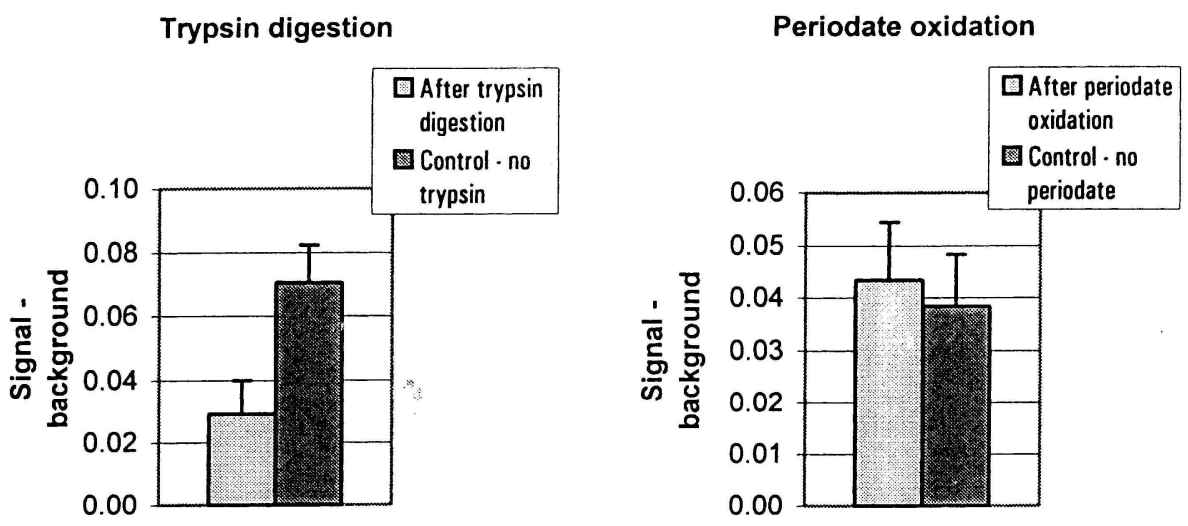

Fig. 3. Effect of epitope degradation by proteolysis or polysaccharide oxidation on the affinity of monoclonal antibody 7B9 for antigen. The procedure is detailed in Section Materials and methods, using casein buffer supplemented with horse serum. Supernatant from Sp2/0 cultures was used as negative serum control. Results are the mean \pm S.D. of five values.

Table 2. Specificities of secreting hybridoma clones produced from spleen cells of mice with immune responses focused against either the anoxic zone or the aerobic zone antigen preparations and of mice with unfocused immune responses. Antisera from all groups of mice were cross-reactive with the antigens. Results shown are for positive hybridoma cell lines stable after at least two clonings

\begin{tabular}{lcccc}
\hline Fusion of origin & $\begin{array}{c}\text { Number of cultures screened (percentage } \\
\text { of total number of wells plated out) }\end{array}$ & $\begin{array}{c}\text { Number of cultures } \\
\text { cross-reactive }\end{array}$ & $\begin{array}{c}\text { Number of } \\
\text { cultures reactive } \\
\text { to anoxic zone } \\
\text { antigen only }\end{array}$ & $\begin{array}{c}\text { Number of } \\
\text { cultures reactive } \\
\text { to aerobic zone } \\
\text { antigen only }\end{array}$ \\
\hline Unfocused & $906(94 \%)$ & 5 & - & - \\
Anti-anoxic zone focused & $480(100 \%)$ & 1 & - & - \\
Anti-aerobic zone focused & $480(100 \%)$ & 3 & - & - \\
\hline
\end{tabular}

stacking gel was composed of $0.13 \mathrm{~mol}^{-1}$ Tris-HCl, $\mathrm{pH} 6.8,0.1 \%(\mathrm{w} / \mathrm{v}) \mathrm{SDS}, 4 \%$ (w/v) acrylamide and $0.1 \%(\mathrm{w} / \mathrm{v}) N^{\prime}, N^{\prime}$-Bis-methylene-acrylamide. The gel solutions were degassed under vacuum for $15 \mathrm{~min}$. Polymerisation was induced by addition of ammonium persulfate and $N, N, N^{\prime}, N^{\prime}$-tetramethylethylenediamine (TEMED) to final concentrations of $0.05 \%$ for the separating gel, and $0.1 \%$ for the

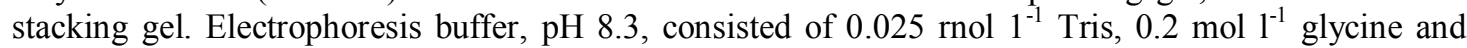
$0.1 \%(\mathrm{w} / \mathrm{v})$ SDS.

The whole cell antigen preparations were pelleted at $12000 \mathrm{x} g$ in a microfuge (Eppendorf, Germany) for $15 \mathrm{~min}$. Pellets were resuspended in reducing sample buffer composed of $0.06 \mathrm{~mol} \mathrm{1}^{-1}$ Tris-HCl, $\mathrm{pH}$ $6.8,10 \%(\mathrm{v} / \mathrm{v})$ glycerol, $2 \%(\mathrm{w} / \mathrm{v}) \mathrm{SDS}, 5 \%(\mathrm{v} / \mathrm{v})$ mercaptoethanol and $0.001 \%(\mathrm{w} / \mathrm{v})$ bromophenol blue to $1 \times 10^{9}$ cells $\mathrm{ml}^{-1}$. After lysis by sonication for $4 \mathrm{~min}, 50 \%$ pulsed, at maximal energy input, samples were heated at $95^{\circ} \mathrm{C}$ for $5 \mathrm{~min}$. Insoluble debris was pelleted by centrifugation at $12000 \mathrm{x} \mathrm{g}$ for $3 \mathrm{~min}$ and the supernatant (100 $\mu 1$ per well) was loaded onto the gel. SDS-PAGE were performed by the method described by Laemmli (1970), modified according to Kiredjian et al. (1986). Proteins were separated on $1.5 \mathrm{~mm}$ thick and $125 \mathrm{~mm}$ long gels. Low $\mathrm{M}_{\mathrm{r}}$ markers (Pharmacia, U.S.A.) and BSA were applied in separate lanes. Pre-electrophoresis was carried out at a constant voltage of $60 \mathrm{~V}$ for $1 \mathrm{~h}$, followed by electrophoresis at $100 \mathrm{~V}$ for $3 \mathrm{~h}$ (Pharmacia).

The gel was equilibrated in a $10 \mathrm{mM}$ CAPS (Sigma, U.S.A.) buffer, $\mathrm{pH} 9.0$, for $15 \mathrm{~min}$ before electroblotting the proteins onto a PVDF membrane (Millipore, U.S.A.) pre-wetted with methanol, followed by CAPS buffer. A Transblot semidry blot apparatus (Bio-Rad, U.S.A.) was used at $10 \mathrm{~V}$ for $45 \mathrm{~min}$.

The strip of PVDF membrane containing the lanes with the $\mathrm{M}_{\mathrm{r}}$ markers and the BSA was cut off and 
stained in destaining solution (methanol, acetic acid and distilled water in a volume ratio of 1:2:1) containing $0.25 \%$ Coomassie blue (Bio-Rad), then destained overnight in destaining solution. The sample-containing part of the membrane was cut as required and blocked for $1 \mathrm{~h}$ in TBS (20 mM Tris, $9 \%(\mathrm{w} / \mathrm{v}) \mathrm{NaCl}, \mathrm{pH} 7.4)$ containing $1 \%$ skimmed milk powder (Elite, Roodepoort, South Africa) and $0.05 \%$ Tween-20. The membrane strips were incubated separately overnight at room temperature in the individual mature hybridoma culture supernatants. Each strip was washed three times in washing buffer $(0.1 \%$ skimmed milk powder in TBS) for 5 min before incubation at room temperature in goat antimouse IgG (heavy and light chain) peroxidase conjugate (Cappel, U.S.A.) diluted 1:1000 with the blocking buffer. After washing as before, the strips were developed in substrate buffer $(0.05 \%(\mathrm{w} / \mathrm{v}) 4-$ chloronaphthol, cold methanol to $17 \%(\mathrm{v} / \mathrm{v})$ and $0.05 \%(\mathrm{v} / \mathrm{v})$ hydrogen peroxide in TBS) until bands showed clearly. Development was stopped by rinsing with distilled water and the strips were photographed.

\section{RESULTS}

The preparation of immunogen from activated sludge proved more complex than is usually the case with bacterial pure cultures. Bacterial cells in activated sludge are largely enmeshed in flocs, requiring dispersion of these aggregates before immunisation. Washing of activated sludge cells before immunising was required to remove material exuded into the surrounding sludge liquor such as enzymes and exoglycans, to minimise nonspecific responses. In the procedure for antigen preparation from activated sludge, washing of cells with water after floc disruption resulted in minimal reaggregation. The sonication regimen yielded a maximal decrease in particulates as well as adequate protein release (results not shown). The mixed lysed and whole cell suspension of the antigen preparation served to ensure that no intracellular or membrane-bound antigen was missed during immunisation and screening.

This yielded similar results: no monoclonal antibodies able to distinguish such antigenic differences could be produced, not even from the immunofocused mice (Table 2). The chance of finding a stable hybridoma clone secreting antibody with such unique specificity appeared to be less than $0.1 \%$ (i.e. no such clones found out of 1000 wells screened), suggesting low abundance of antigens exclusive to either zone.

Nine stable hybridoma clones, secreting cross-reactive monoclonal antibodies, were used in an attempt to distinguish between antigen preparations from the aerobic zones of two activated sludge systems with different phosphate removal abilities. One monoclonal antibody, 7B9, derived from an anti-aerobic zone focused mouse and being of the IgM class, showed selectivity for the antigen preparation from the system significantly removing phosphate (Fig. 1). This was confirmed by Western blot (Fig. 2). The antibody showed five compact bands occurring uniquely in the system successful at phosphate removal. Although limited by the resolution achieved in the separation, the $M_{T}$ of the bands appeared to be multiples of $18 \mathrm{kDa}$, probably representing an oligomeric protein in different stages of covalent oligomerisation

To establish the molecular nature of the epitope recognised by antibody 7B9, epitope degradation strategies were employed (Fig. 3). ELISA signals were practically unchanged after periodate oxidation, but much diminished after trypsination, indicating the character of the epitope to be proteinaceous.

\section{DISCUSSION}

This study was aimed at the development of immunochemical probes to determine and monitor phenotypic traits of the activated sludge phosphate removal process. The antibodies were used to evaluate the phenotypic status pertaining to different zones in a phosphate removing system (configured to contain anaerobic, anoxic and aerobic stages), as well as to equivalent zones (aerobic) in activated sludge systems differing in configuration and thus phosphate removal ability.

Antigenic differences between the anoxic and aerobic zones of a phosphate removing activated sludge system were not distinguished either by polyclonal or monoclonal antibodies. This confirmed the expectation that such differences would be small, if in fact they existed at all, as flow-through and mixing of zonal contents was continual in an activated sludge system. It was found previously that under aerobic and anaerobic conditions the same activated sludge microbial community was responsible for the overall EBPR process, since similar behaviour was displayed regarding phosphate uptake and release (Muyima, 1995).

Examining SDS-PAGE protein profiles of total protein extractions from activated sludge, Louw (1996) found little, if any differences between the SDS-PAGE protein profiles of total protein extracts 
from phosphate removing (aerobic) and non-phosphate removing (anaerobic) zones, arguing against any significant shift in microbial populations or enzyme expression between the two reactors. The antigen preparations were used for immunisation in both the conventional and the immunofocused anti-serum production protocols described in Section Materials and methods. Antisera obtained from either strategy were unable to distinguish antigenically between the anoxic and aerobic zones of a phosphate removing activated sludge system (results not shown), prompting a monoclonal approach. It may be deduced that if phenotypic differences were present during that study, these were too slight to be resolved by SDSPAGE protein profiles. The absence of immunochemical resolution as demonstrated in the current study tends to confirm the findings of these workers.

No indication could be found in current literature of the involvement of an $18 \mathrm{kDa}$ protein that might be involved in the removal of phosphate from the environment by bacteria (Akiyama et al, 1992; Kampfer et al, 1992; Bonting et al, 1993; Van Veen et al, 1993a,b; Kortstee et al, 1994). This does not imply that the $18 \mathrm{kDa}$ could not be involved in phosphate removal, as the process is currently not fully understood and characterised, while interspecies variation of mechanisms of phosphate removal is, at this stage, an open field of research.

In order to increase the probability of finding antibodies to rare antigens in the anoxic and especially the aerobic zones, both conventional and immunofocused strategies were employed for immunisation. The use of more than one immunisation schedule was, in fact, highly recommended by Galfre and Milstein (1981) in their classic protocol for hybridoma production. Neither improvement in resolution nor enhancement of the immune response by the immunofocusing was clearly seen. It may be noted, however, that the monoclonal antibody capable of resolving phenotypic differences between two activated sludge systems as discussed below is a product of the immunofocused immunisation strategy. Whether this was manifested by chance or design cannot be determined. The results in Table 2 would suggest a very low frequency $(<0.5 \%)$ of occurrence of stable antibodies that recognised antigens in the anoxic and aerobic zones. The finding that one of the nine stable antibodies produced, recognised antigen in the could mean a relatively high abundance $(>10 \%)$ of the $18 \mathrm{kDa}$ antigen, but because only one such antibody was found, the statistics are not reliable and the antibody could merely be a lucky find.

A significant finding emerging from this study was based on the observation that antigenic differences were clearly detected between the aerobic zones of two activated sludge systems with differing phosphate removal ability. A monoclonal antibody was found that was capable of distinguishing between the two systems both by ELISA and immunoblot. Characterisation of the antigen recognised suggested a protein nature. The antibody showed five compact bands on the blot, with $M_{x}$ appearing to be multiples of $18 \mathrm{kDa}$. The epitope recognised probably occurred on an $18 \mathrm{kDa}$ proteinaceous monomer, represented on the blot in incremental steps of subunit association. Of note is the fact that the two activated sludge systems compared, received identical influents, and that they differed only in their configuration: the non-phosphate removing system lacking an anaerobic zone, this zone being the key to establishing the EBPR process in activated sludge (Kortstee et al, 1994).

The existence of the unique antigen in the phosphate removing system may be speculated upon: either the specific conditions prevailing in the phosphate removing system as opposed to the non-phosphate removing system could have induced its expression, or the anaerobic zone selected for a unique bacterial population in the phosphate removing system which was recognised by the antibody, but is not necessarily correlated with phosphate removal. In addition, the state of oligomerisation of the $18 \mathrm{kDa}$ protein could possibly correlate to the phosphate removing ability of the sludge. Future research could therefore aim at finding answers to resolve these issues.

Acknowledgements - The authors are indebted to Professor M. C. Wentzel, Department of Civil Engineering, University of Cape Town, South Africa, for providing samples; and the Water Research Commission of South Africa for financial support.

\section{REFERENCES}

Akiyama M., Crooke E. and Kronberg A. (1992) The polyphosphate kinase gene of Escherichia coll The Journal of Biological Chemistry 261, 22556-22561.

Bonting C. F. C, Kortstee G. J. J. and Zehnder A. J. B. (1993) Properties of polyphosphatase of Acinetobacter johnsonii 210A. Antonie van Leeuwenhoek 64, 75-81.

Boshoff C. H. (1991) Spontaneous cell fusion induced by bacterial immunisation. M.Sc. thesis, Faculty of Science, University of Pretoria.

Cooper P., Day M. and Thomas V. (1994) Process options for phosphorus and nitrogen removal from wastewater. Journal of the Institution of Water and Environmental Management 8, 84-92.

Crause J. C. (1993) Biochemical characterisation of the paralysis toxin of Rhipicephalus evertsi evertsi. Ph.D. thesis, Faculty of Science, University of Pretoria.

Fleit E. (1995) Intracellular $\mathrm{pH}$ regulation in biological excess phosphorus removal systems. Water 
Research 29, 1787-1792.

Furniss B. S., Hannaford A. J., Smith P. W. G. and Tatchell A. R. (1989) VOGEL's Textbook of practical organic chemistry, 5. In Longman Scientific and Technical. lohn Wiley and Sons, New York.

Galfré G. and Milstein C. (1981) Preparation of monoclonal antibodies: strategies and procedures. Methods in Enzymology 73, $3^{\wedge} 16$.

Geiger R. and Fritz H. (1984) Methods of Enzymatic Analysis, 3rd edition, Vol V, ed. H. U. Bergmeyer, pp. 119-120. Verlag Chemie, Weinheim.

Henze M. (1996) Biological phosphorus removal from wastewater: processes and technology. Tenth Forum for Applied Biotechnology, 26-27 September 1996. University of Gent, Belgium.

Kämpfer P., Bark K., Busse H. I., Auling G. and Dott W. (1992) Numerical and chemotaxonomy of polyphosphate accumulating Acinetobacter strains with high polyphosphate: AMP phosphotransferase (PPAT) activity. Systematic and Applied Microbiology 15, 409-419.

Kiredjian M., Holmes B., Kersters K., Guilvout I. and De Ley I. (1986) Alcaligenes piechaudii, a new species of human clinical specimens and the environment. International Journal of Systematic Bacteriology 36, 282-287.

Knight G. C, Seviour E. M., Seviour R. I., Soddell I. A., Lindrea K. C, Strachan W., De Grey B. and Bayly R. C. (1995) Development of the microbial community of a full scale biological nutrient removal activated sludge plant during start-up. Water Research 29, 2085-2093.

Kortstee G. I. I., Appeldoorn K. I., Bonting C. F. C, Van Mel E. W. I. and Van Veen H. W. (1994) Biology of polyphosphate-accumulating bacteria involved in enhanced biological phosphorus removal. FEMS Microbiology Reviews 15, 137-153.

Laemmli U. K. (1970) Cleavage of structural proteins during assembly of the head of bacteriophage T4. Nature 227, 680-685.

Louw D. I. R. (1996) The community structure of activated sludge determined using DNA reassociation and polyacrylamide gel electrophoresis. M.Sc. thesis, Faculty of Biological and Agricultural Sciences, University of Pretoria.

Matthew W. D. and Patterson P. H. (1983) The production of a monoclonal antibody that blocks the action of a neurite outgrowth-promoting factor. Cold Spring Harbor Symposium of Quantitative Biology 48, 625-631.

Matthew W. D. and Sandroch A. W. (1987) Cyclophosphamide treatment used to manipulate the immune response for the production of monoclonal antibodies. Journal of Immunological Methods $100,73-82$

Mino T., Liu W. T., Kurisu F. and Matsuo T. (1995) Modelling glycogen storage and denitrification capability of microorganisms in enhanced biological phosphate removal processes. Water Science and Technology 31, 25-34.

Moreno I., Puig-Roque O., Nevado I. I. and Garcia-Ferris C. (1994) Testing the a-amylase inhibitor of the common bean. Journal of Chemical Education 71, 350-351.

Muyima N. Y. O. (1995) Phosphate uptake by immobilised activated sludge in activated sludge mixed liquor. Ph.D. thesis, Faculty of Biological and Agricultural Sciences, University of Pretoria.

Sanden B., Grunditz C, Hansson Y. and Dalhammar G. (1994) Quantification and characterisation of Nitro-somonas and Nitrobacter using monoclonal antibodies. Water Science and Technology 29, 1-6.

Schon G., Geywitz S. and Mertens F. (1993) Influence of dissolved oxygen and oxidation-reduction potential on phosphate release and uptake by activated sludge from sewage plants with enhanced biological phosphorus removal. Water Research 27, 349-354.

Smith L. V. (1988) Production of monoclonal antibodies against an organism isolated from greening diseased citrus. M.Sc. thesis, Faculty of Science, University of Pretoria.

Smolders G. I. F., Van der Meij I., Van Loosdrecht M. C. M. and Heijnen I. I. (1994a) Model of the anaerobic metabolism of the biological phosphorus removal process: stoichiometry and $\mathrm{pH}$ influence. Biotechnology and Bioengineering 43, 461-470.

Smolders G. I. F., Van der Meij I., Van Loosdrecht M. C. M. and Heijnen I. I. (1994b) Stoichiometric model of the aerobic metabolism of the biological phosphorus removal process. Biotechnology and Bioengineering 44, 837-848.

Sorm R., Bortone G., Saltarelli R., Jenicek P., Wanner I. and Tilche A. (1996) Phosphate uptake under anoxic conditions and fixed-film nitrification in nutrient removal activated sludge system. Water Research 30, 1573-1584.

Toerien D. F., Gerber A., Lotter L. H. and Cloete T. E. (1990) Enhanced biological phosphorus removal in activated sludge systems. Advances in Microbial Ecology 11, 173-230.

Van Veen H. W., Abee T., Kortstee G. I. I., Konings W. N. and Zehnder A. I. B. (1993a) Characterisation of two phosphate transport systems in Acinetobacter johnsonii 210A. Journal of Biological Chemistry 268, 7-19383.

Van Veen H. W., Abee T., Kortstee G. I. I., Konings W. N. and Zehnder A. I. B. (1993b) Mechanism and energetics of the secondary phosphate transport system of Acinetobacter johnsonni 210A. Journal of Biological Chemistry 268, 7-19383. 